\title{
Muslimani kot drugi v folklori in literaturi: med reprezentacijami in dejstvi
}

\author{
Muslims as Others in Folklore and Literature. \\ Between Representations and Facts
}

\begin{abstract}
Povzetek: Na podlagi tekstualne in kontekstualne analize besedil, spoznanj folkloristike, zgodovine in sociologije smo raziskovali upodobitve islama in pripadnika islama v literaturi in folklori. Spraševali smo se, ali so se podobe drugega morda oblikovale tudi ob teh tematizacijah. V članku presojamo, ali je stereotipizacija islama in njegova večinoma negativna podoba, znana iz folklornih in literarnih besedil, vplivala na odnos do islama kot religije in prek tega tudi do pripadnikov te religije ter ali se ta negativna podoba sčasoma lahko preoblikuje v pozitivno. Analizirali smo izbrane ljudske pesmi, ljudske pripovedi ter literarna besedila od Aškerca do sodobnosti glede na reprezentacijo in konceptualizacijo islama. Na podlagi analize besedil in teoretskih spoznanj ugotavljamo, da podoba muslimana ali Turka iz folklore in literature 19. stoletja prikazuje ontološko, religiozno in kulturno drugačnega tujega, kar povzroča odpor. Toda ko pesnik Aškerc obišče muslimansko okolje konec 19. stoletja, gre za časovni in personalni odmik od obdobja turških vpadov, in takrat se stereotipizacija prekine, drugačna izkušnja stika $z$ islamom ga celo navduši, $v$ njem odkriva podobnosti s krščanstvom, hkrati pa eksotiko, ki ga še posebej privlači. A še vedno se v pesmih skrivajo kritični toni. Negativna podoba pripadnikov islama v folklori in literaturi 19. stoletja prevladuje, saj je kolektivni spomin na turško divjanje in povezanost islama in muslimanov z nasiljem izjemno trdovraten. Drugače pa je v literaturi prve svetovne vojne, saj je prav zaradi eksistencialne ogroženosti vseh udeležencev vojne v njej odsotna bojazen pred drugim, ki je muslimanske vere. Odnos do muslimanskega drugega po letu 1991 pa je predstavljen nevtralno, morda so negativne le tiste podobe, ki izhajajo iz arabskega sveta, sveta, ki je bil preveč oddaljen od nas in ga nismo poznali. Razprava je poskusila zajeti različnost odnosov do muslimanskega drugega, tako kot jih je bilo mogoče razbrati iz reprezentacij. Slovstvena podoba islama tako ni recept za dialog z drugim in drugačnim, je le možnost, da prek teh tematizacij ugotavljamo enoplastnost ali večplastnost teh podob. Ne moremo pa v analizo teh podob niti v njihov kontekstualni okvir aplicirati sodobnih medreligijskih trendov. Sodobna spoznanja, da dialog lahko poteka le na osebni ravni, da je mogoč le ob sprejemanju kulturne in religiozne različnosti, ki pa izhaja iz preseganja doktrinalnih in dogmatskih zapovedi tako islama kot krščanstva, vidimo tudi v nekaterih analiziranih besedilih. ${ }^{1}$
\end{abstract}

1 Članek je bil pripravljen v okviru raziskovalnega programa Folkloristične in etnološke raziskave ljudske duhovne kulture (P6-0111), ki ga iz državnega proračuna sofinancira Javna agencija za raziskovalno dejavnost Republike Slovenije. 
Ključne besede: muslimani, folklora, literatura, reprezentacije, drugi, kultura, religija

\begin{abstract}
On the basis of textual and contextual analysis of texts, knowledge of folkloristics, history and sociology, we have identified depictions of Islam and members of Islam in literature and folklore. We hypothesize that images of the Other might have formed along these themes. The article examines whether the stereotyping of Islam and its mostly negative image, known from folklore and literary texts, have influenced attitudes towards Islam as a religion and, consequently, its members, and whether this negative image can be transformed into a positive one over time. We analysed selected folk songs, folk tales, and literary texts from Aškerc to the present with regard to the representation and conceptualization of Islam. Based on the analysis of texts and theoretical findings, we find that the image of Muslims/Turks in the $19^{\text {th }}$ century folklore and literature, portrays the Other ontologically, religiously and culturally different, which in turn causes resistance. However, when the poet Aškerc visits the Muslim environment at the end of the 19th century, a temporal and personal break from the period of the Turkish invasions occurs; stereotyping is already interrupted, a new experience of contact with Islam even impresses him, he discovers similarities with Christianity and is fascinated by the exotic. But there are still critical tones in his poems. The negative image of the adherent of Islam is prevalent in folklore and literature of the $19^{\text {th }}$ century, since the collective memory of Turkish savagery and the connection of Islam and Muslims with violence is extremely persistent. It is different in the literature of the First World War. The reason for the change was the existential threat of all participants in the war that consequently caused the lack of the fear from the Other of the Muslim religion. After 1991, the attitude towards the Muslim Other is presented in a neutral way, except for the images from the Arab world, a world unknown and too far from us, that may be slightly negative. The article sought to capture the diversity of attitudes towards the Muslim Other as could be seen from the representations. The folklore and literary image of Islam is thus not a recipe for dialogue with the Other and the different but merely a possibility to identify single- or multiple-layered images through these representations. However, contemporary interreligious trends cannot be applied to the analysis of these images nor to their contextual framework. The contemporary awareness that dialogue can take place only on a personal level, that it is possible only along with the acceptance of cultural and religious diversity, which results from transcending the doctrinal and dogmatic commandments of Islam and Christianity, is also seen in some of the analysed texts.
\end{abstract}

Key words: Muslims, folklore, literature, representations, Other, culture, religion

\title{
Uvod
}

Bližina islamskega sveta (Jezernik 2011, 2012; Todorova 2001) in njegovi pozitivni ter negativni vplivi so nedvomno pripomogli k percepciji tega sveta $v$ vseh njegovih stereotipih, saj je vedenje o tem svetu - in v povezavi z njim tudi religija - pokazalo, da je slovenska družba percepcijo gradila večinoma na sprejemanju nepreverjenih in posplošenih informacij o muslimanih, islamu in s tem povezanem družbeno-kulturnem ozadju. Po Todorovi je bil Balkan kot most med krščanstvom in islamom generator razlik z Evropo. Kljub temu pa so, kar se je pokazalo kasneje, meje med muslimani in kristjani, ki so se utrdile v stoletjih otomanskega vladanja, ostale $(2001,185,271)$. Predvsem so to negativne predstave o islamu v evropskem prostoru (Kalčić 2007; Monta 2011; Said 1996; Voje 1996 idr.), 
ki so temeljile na negativnih pojmovanjih zgodovinskih turških pohodov in vdorov v evropski prostor ter nato na oblikovanju negativnih podob o vsakem pripadniku islama kot potencialnemu nasilnežu in kasneje teroristu. Zato je t. i. protiislamski diskurz (še posebno danes ob begunski krizi in nevarnosti terorizma) temeljil na tem, da je islam inherentno sovražen racionalni misli (Šterbenc 2005, 2017). Pomanjkanje znanja ali celo popolno nepoznavanje tega, da je bila islamska civilizacija na vseh znanstvenih in filozofskih področjih v zgodovini močna supersila, in to v času, ko se je zahodna civilizacija šele vzpostavljala, je seveda vplivalo tudi na to, da je pogled na islam in muslimane izkrivljen (Mastnak v Šterbenc 2005, 305). Pa ne gre le za dve različni religiji, gre tudi za dve različni kulturi, ki sta trčili predvsem zaradi nerazumevanja kultur ter politike osvajanja ozemlja.

Prav drugačnost kulture in religije ter vdor drugega v zahodna krščanska okolja in izvajanje nasilja je odločilno vplivalo na tematizacijo islama kot sovražne religije in njegovega nosilca kot sovražnika tako $v$ folklori in literaturi, označenega z besedo Turek, ki je bila sinonim za muslimane. Za reprezentacije pa je značilno, da niso samo preslikava resničnosti, temveč jih oblikuje tudi splošen pogled na svet, značilen za folkloro, ali pa avtorjev pogled na svet, ki je posledica njegove vpetosti ali celo ujetosti v različne družbenopolitične sisteme.

\section{Koncepti in raziskovalna vprašanja}

Na podlagi tekstualnih in kontekstualnih analiz posameznih besedil bomo ugotavljali, kakšne so bile te upodobitve v folklori in literaturi in ali so morda prav s pomočjo teh tematizacij oblikovale podobo muslimanskega drugega. Na podlagi reprezentacij islama in pripadnika islama kot drugega želimo ugotoviti, (1) ali sta stereotipizacija islama in njegova večinoma negativna podoba, znana iz folklornih in literarnih besedil, vplivali na odnos do islama kot religije in prek tega tudi do pripadnikov te religije; (2) ali je bil islam kot religija pravzaprav v ozadju in ali je bila povezava islama z nasiljem večinoma neodvisna od same religije; (3) ali je bila morda stereotipizacija islama zgolj odsev nekih popolnoma zgrešenih pogledov tako na religijo kot na njene pripadnike. 
$\mathrm{Z}$ analizo besedil, izbranih glede na reprezentacijo in konceptualizacijo drugega in podobe islama, ki so kanonizirane v slovenskem prostoru in predstavljajo kolektivni zgodovinski in kulturni spomin, želimo ugotoviti, (1) ali bi prav te podobe lahko postavili v družbenopolitični kontekst; (2) ali se imaginarne in fiktivne podobe skladajo z resničnostjo, predstavami skupnosti ali individuuma o njih; (3) kako kot v ogledalu odseva tudi obraz drugega, in s pozitivnimi tematizacijami okrepiti povezujoče dejavnike med različnimi religijami in kulturami.

\section{Reprezentacije islama v evropskem prostoru}

V evropskem prostoru je tematizacija islama v folklori in literaturi obsežna in je večinoma portret drugega, ki se giblje od fasciniranosti in eksotičnosti preko stereotipizacije vse do zelo negativne prezentacije, kar pomeni, da gre za zahodno percepcijo Turka in islama (Chambers 2015; Cheesmann 2007; 2012; May 2009; Rushdie 1991). Reprezentacija islama in njegovega pripadnika je v različnih obdobjih različna, saj se diskurzivno pojavlja od upodobitve otomanskega Turka, nosilca druge vere in osvajalca, prek eksotičnega tujca do tistega, ki v evropskem prostoru danes pomeni »antitezo« Evrope oz. evropskosti (Todorova 2001, 36-37). Drugi iz Orienta je bil po Saidu oblikovan na podlagi zahodnih predstav in empirične realnosti, a mnogo bolj fiktiven kot resničen (Said 1996, 19, 25). Konstrukcija tega "tujega" ali človeka iz tujih svetov, ki je videti drugače in veruje drugače in je grožnja evropskim vrednotam, je tudi v fiktivnem svetu folklore odsev resničnosti, večinoma v literaturi, a se včasih reprezentacije in dejstva ne skladajo. Odkloni od te večinske percepcije so redki. Tako ugotavljamo, da Turek kot sinonim za muslimana odseva tudi iz evropske folklore, kjer je zadržanost do Turkov povezana s kulturno drugačnostjo in religiozno diferenco. Evokacija Turkov je v evropski folklori večinoma negativna, saj so predstavljeni kot agresorji (Kumer 1996). Turek je vključen v različna evropska literarna dela (npr. Marlow in Shakespeare; Goethe, ki je v svoja dela vključil citat iz Korana /1819/ idr. /May 2009/) vse do sodobne literature (Rushdie 1991). 


\section{Reprezentacije islama v slovenskem prostoru}

Reprezentacije islama v slovenski folklori (Kumer 1996; Golež Kaučič 2007b; Turk 2010; Mlakar 2016) in literaturi (Hladnik 2009; Jaklitsch Jakše 2012; Potisk 2013) ter kulturi in družbi (Šmitek 1986; Vinkler 2009; Vobič Arlič 2009; Jezernik 2011, 2012) izhajajo iz družbenozgodovinskih koncepcij islama in iz neposrednih izkušenj, ki so jih imeli prebivalci slovenskega prostora v stikih z njimi. Baskar meni: »V slovenskem kolektivnem spominu se je ohranila precej homogena slika Turka, ki se sklada s konceptom obmejnega orientalizma. Tega je Andre Gringrich $(1996,121)$ definiral kot varianto orientalizma, ki pojasnjuje odnos do 'muslimanskega drugega' v tistih delih Evrope, ki so bili v dolgotrajnih stikih z muslimani ali pa so bili del Osmanskega cesarstva, torej tudi v deželah habsburškega cesarstva. Obmejni orientalizem pogosto spremlja ideja o antemurale christianitatis', pri kateri gre za poveličevanje vloge lastne skupnosti pri obrambi krščanstva in zahodne civilizacije pred muslimanskim drugim." (Baskar 2012, 139-140; Jezernik 2012, 21) Zato lahko rečemo, da so podobe Turka/muslimana v folklori, literaturi in družbenopolitičnem prostoru zelo podobne kot $\mathrm{v}$ preostalem evropskem prostoru, a s to razliko, da so v nekaterih obdobjih (kot sta prva svetovna vojna in socializem) vendarle imeli drugačen odnos predvsem do tistih pripadnikov islama, s katerimi so sodelovali ali sobivali. Kljub temu se tudi v sodobnem romanu pozitivna percepcija včasih razlomi, ko so tematizirani prebivalci arabskega prostora in njihova taka ali drugačna povezanost s Slovenci.

\subsection{Obdobje kulturnega spomina na turške vpade ter t. i. protiturška vstaja (1878) in s tem povezane tematizacije v folklori}

Analizirane pesmi so: Turki pred Dunajem, Zmaga nad Turki pri Sisku, Školastika, Mlada Breda, Kralj Matjaž, Deklica vojak, Je bla v Bosni vojska (1878) (Golež Kaučič 2007b, 2013; Mlakar 2014, 2019; Dapit 2017) idr.

Saraceni ali Mavri so prvi kot pripadniki islama predstavljali nevarnost za slovenskega človeka, kar odseva v najbolj znani baladi Lepa Vida. Šmitek meni: »Ljudsko izročilo najpogosteje povezuje in pojasnjuje moralno izprijenost tujcev z njihovo nekrščansko vero, kar kaže tudi na močno versko indoktrinacijo.« $(1986,11)$ V 15. stoletju so saracensko nevarnost zamenjali Turki. Seveda to niso bili Turki, temveč Osmani, in po Vojetu »so slovenske 
dežele napadale predvsem čete spahijske vojske iz bosenskega in sosednjih sandžakov, ki so bile večinoma sestavljene iz prebivalstva južnoslovanske etnične pripadnosti« $(1996,56)$. Turške čete so, kot rečeno, prihajale iz Bosne, muslimanski Turki so v pesmi prevzeli vlogo Saracenov, turški car je v variantah že obstoječih pesmi ali v novonastalih stopil na mesto španskega kralja. Turški car je snubec Školastike, ki se njegove snubitve reši tako, da jo zaradi njene pobožnosti rešijo angeli, skratka transcendenca (Š 38); ${ }^{2}$ turški car pride po mlado Bredo v baladi o smrti nesrečne neveste, ki umre pred poroko (Š 101; SLP V³/241 C). Turki odpeljejo kralju Matjažu Alenčico v globoko Turčijo, ki pa ne pomeni maloazijske Turčije, temveč balkanske dežele, ki so jih zavojevali Turki:
Peršli Turči so hudi,
poropali so pow hradi,
so ukradli mwado Lenčico,
so ubili staro mamico. ${ }^{4}$

Kralj Matjaž je slovenski Matija Korvin, ki se je resnično bojeval s Turki, čeprav je vpis njegovega imena kasnejši in včasih ne predstavlja zgodovinske osebnosti. Obstaja pa tudi pesem o reševanju kralja Matjaža iz turške ječe. Iz nje ga rešuje hčerka turškega carja. Ta balada je bila najbolj razširjena v Reziji (italijanski pokrajini, kjer živi slovenska manjšina/Golež Kaučič 2007b in Dapit 2017/). Ne Saraceni ne Turki niso bili resnična etnična označitev, ampak le simbol za zavojevalce, roparje in religiozno označene pogane, kajti folklorna označitev se ne meni za zgodovinska dejstva. Prav zaradi ropanja in ugrabitev ljudi so bili Turki osovraženi. Turek je poosebljal strah, nevarnost, zlo. O turških ugrabitvah pojeta dve slovenski baladi: balada o tem, kako turški vojak ponudi deklici, ki s Turkinjami na Turškem žanje pšenico, da jo odpelje domov (Š 93). Ko prideta k njenim domačim in ti Turka neprijazno sprejmejo, fant razodene, da je v resnici domači sin, ki je bil pred mnogimi leti ugrabljen na Turško, nato pa se žalosten vrne tja. Druga govori o bratu in sestri plemenitega rodu, ki sta v turškem ujetništvu že sedem let in pol, ko po naključju izvesta za svoje poreklo in nato zbežita

\footnotetext{
$2 \quad$ Š $93=$ Štrekelj, 1895. Številka označuje pesemski tip.

3 SLP V/ 241 C = peta knjiga in tip št. 241 C (Golež Kaučič, Marjetka, et al., 2007a).

4 Iz Šmarjete pri Rožu, Koroška, 1840: Kralj Matjaž reši svojo ugrabljeno ženo.
} 
domov (Š 95). Ena izmed znamenitih balad o deklici vojaku, ki maščuje bratovo smrt, pa je tudi tematizirala turške poboje. V njej se Alenčica, ki so ji Turki ubili brata Gregca, v turški preobleki poda v Turčijo in pobije toliko Turkov, da se turški car začne bati, da morda to le ni Gregec, ki sploh ni bil ubit. Alenčica pa tedaj pokaže, da je dekle, in izgine (SLP I/755). (Kumer 1996, 147-151) Zanimivost v baladnem izročilu je, da so »Turki« večinoma slovenskega porekla.

Leta 1578 so v tiskarni Janža Mandelca v Ljubljani kot odziv na padec Metlike (dve leti prej) natisnili letak Neuwe Zeitung, ki na štirih straneh popisuje, kaj se je zgodilo s premaganci: »mestnega sodnika so turški vojaki ustrelili z lokom, mestne svetovalce skrajšali za glavo, žene in hčere meščanov spravili ob čast, nazadnje so nesrečnice končale v cerkvi, ki so jo ob odhodu zažgali, čete Farhat paše pa so uplenile tudi 900 mož in dečkov, ki so jih odvedli v sužnost.« (Gruden 1912, 777; nav. po Vinkler 2011, 106-107) Odsev tega dogodka ter medbesedilno povezavo prek citata ljudske pesmi Deklica vojak najdemo v povesti Hči grofa Blagaja (1911-1913) je izhajala v Ljubljanskem zvonu, 1954 izšla kot Lepi janičar):

Se Alenčica hitro usuknila,

na konjiča urno je smuknila.

Je Lenčica daleč dirjala,

daleč, oj daleč v ravno poljé.

Višji soldat v lini stoji

pa tako pravi pa govori:

Sem spodrči Rožmanov soldat,

žensko telo je presrčnó,

moško telo je prelepó;

mi ga pa moramo skušati.

Národná (245)

Rožmanova Lenčica postane janičar Omar, ki je v resnici kontesa Alijana, hči grofa Blagaja. 
V povesti nekdanji janičar stereotipno opiše divjanje Turkov:

Bili smo v Slavoniji, na Kranjskem in Štajerskem, na Ogrskem in Sedmograškem. Jahali smo po cele noči. Pobijali, robili, palili in jemali smo vse, kar smo le dosegli, vse do opankov! Samo na Kranjskem in Štajerskem smo razrušili ali poškodovali nad šestdeset cerkva, požgali več samostanov, pet trgov in do dvesto vasi in odgnali okoli petnajst tisoč nevernikov. Alah je velik! (141)

Turki pred Dunajem je pesem, ki poje o turških vpadih od 14. do 16. stoletja, ko je vojska Osmanskega cesarstva večkrat vdrla v habsburške dežele (slovenske dežele pod Habsburžani so bile Kranjska, Štajerska, Koroška, Goriška in Trst). Vse štiri variante (žal brez melodij) prinašajo kar nekaj zgodovinskih odsevov: „V Dunaj je pisal hudi Turk / k cesarju svitlemu, / al se udate, al se podaste, / al daste ključe od Dunaja." (SLP I/13/16) Verjetno je bil to Kara Mustafa, poveljnik turške vojske ob drugem obleganju Dunaja leta 1683, ko je pozval oblegance k predaji, cesarja Leopolda I. pa tedaj ni bilo več v mestu. Pesem je seveda vse poenostavila in tematizirala le zmago, ki je prišla s pomočjo nadnaravne pomoči - "Marija v oblaku stoji, / močno proti Turku perti«(SLP I/13/1) (gre za boj dveh ver). Ta je prišla v osebi "poljskega kralja (Jan Sobieski), "parskega kneza" (bavarski volilni knez Maksimiljan Emanuel), Holendarce« (to naj bi bili Holandija in Anglija, ki pa v resnici nista sodelovali pri reševanju Dunaja, kajti veliki aliansi sta se pridružili šele leta 1688).?

Zgodovinska pripovedna pesem Ravbar zbira vojsko in zmaga pri Sisku upesnjuje znamenito bitko pri Sisku (22. 6. 1593), ki je bila ena pomembnih zmag krščanske vojske nad Turki, saj je napravila konec turškemu prodiranju na zahodni Balkan. Habsburžani so tako ustvarili ravnovesje sil proti Osmanskemu cesarstvu. Tudi za slovenske dežele je turška nevarnost osvajanja prenehala. (Simoniti 1987, 277; Breyer 1943, 244-259) V bitki je preživelo le 20 odstotkov Turkov od 38.000-glave vojske. Veliko jih

6 Kumer et al. 1970. (Slovenske ljudske pesmi, I. knjiga, tip 13, varianta 1)

7 Dramsko upodobitev je ta dogodek dobil v istoimenski drami Franceta Riharja (1910) (Jaklitsh Jakše 2012, 108). 
je padlo v boju, še več pa utonilo v Kolpi. Sodelovale so Kranjska, Koroška in Štajerska. (SLP I/12/1)

Tudi vojna v Bosni leta 1878 je upesnjen dogodek v slovenskem ljudskem pesemskem izročilu (tip Je bla v Bosni vojska/A-E), saj je potovanje $\mathrm{v}$ tujo deželo v ljudeh spodbudilo ustvarjalnost. Po berlinskem kongresu je Avstrija zasedla Bosno in Hercegovino, tako da so v tej vojni sodelovali vsi slovenski polki, med njimi tudi 17. pehotni polk: varianta pesmi A Usnajstega avgusta poje v prvi kitici: „Usnajstega avgusta / je bla u Bozni vojska. / Dragónari mi smo ta prvi bli, / za Turkam smo dírjali« (GNI $\mathrm{O} 449^{8}$ ); 2. kitica variante E s prvim verzom Oh, poslušajte vi znanci pa tematizira veselje nad zmago: „Smo Turka zapodili, smo Bozno pridobili, /: le pijmo pa jejmo za turške moči, / sej Turek že mrtu leži!« (GNI O 6871, Golež Kaučič 2013) ${ }^{9}$

\section{Ljudsko pripovednišstvo}

Anja Mlakar, ki je raziskovala podobo Turka v ljudskem pripovedništvu, meni, da se ta kaže »kot generalizirana, stereotipizirana figura brez lastne individualnosti in z izrazito težnjo po uničevanju, torej kot demonizirani Drugi« (2019, 55). V nadaljevanju navedeni odlomek enodimenzionalne ljudske pripovedi, ki jo je zapisal France Kotnik leta 1957 (60), predstavlja prav to posplošeno podobo Turka. V svojem spominu so jo nosili ustvarjalci folklore in je bila najbrž podlaga za najbolj znano slovensko zgodovinsko povest iz turških časov, imenovano tudi turška povest Miklova Zala Jakoba Sketa (1884), pa tudi za kasnejšo povest Lee Fatur Junakinja zvestobe, objavljeno v reviji Ženski svet (1927-1928).

Že več ko sedmi rod je zamrl - pripovedujejo narodne pripovedke - kar so divji Turki po naši dolini mandrali. Konje so imeli narobe podkovane. Bilo jih je kot listja in trave. Vsi ljudje so morali zapustiti svoje hiše in se umakniti na gore in planine. Kogar so

$8 \quad \mathrm{O}=$ označuje zbirko OSNP: Odbor za nabiranje narodnih pesmi (1903--1913).

9 Enodejanka Kosana (1870) Josipa Stritarja pa tematizira avstrijsko okupacijo Bosne (gl. tudi Jaklitsch Jakše 2012: 107). V vseh dramskih delih je navzoča stereotipna podoba Turka kot krutega nasilneža. 
v roke dobili, gorje si ga njemu! "Ne boj se, ne boj se,« in glava je odletela. Brez vsega usmiljenja so privezovali nekatere za noge h konskim repom in jo napeli potem v najhitrejšem diru čez polja in travnike, čez pečevje in prodovje, da se je truplo na stotero koscev razdrobilo. Druge so obešali na veje; nekatere celo k drevesom pripenjali in meso z njih rezali. Kar je bilo pa krepkejših mož in lepših devic, so jih odpeljali s seboj v globoko Turčijo. Prav taka se je zgodila mladi Miklji, Zala imenovani. ${ }^{10}$

\section{Slovenska književnost}

Miran Hladnik v članku Turki v slovenski zgodovinski povesti napiše, da "so Turki pomemben del snovnega, tematskega in motivnega repertoarja slovenske literature, največ v ljudski pesmi in poljudni pripovedni prozi. Turška povest je eden najbolj trdoživih žanrskih tipov zgodovinskega romana na Slovenskem [...] Najbolj intenzivno so jo pisali v 60. in 70. letih 19. stoletja in v prvih štirih desetletjih 20. stoletja." (2011, 253-254) Za središče vzame Jurija Kozjaka11 Josipa Jurčiča, ki tematizira obdobje 1464-1475, ko so Turki pod vodstvom Ahmeda paše požgali stiški samostan, in zgodbo o janičarju, ki se vrne domov na Kranjsko in se odreče islamu (1864). Tematizacija islama in njegovih pripadnikov, ki nasilno vdirajo na Kranjsko, je tudi $v$ teh povestih ostala le negativna.

Tudi Aškerčeva tematizacija Turka je negativna v pesmih Janičar, Brodnik ${ }^{12}$ in Vaška lipa. V njej nadaljuje opis nasilja turških zavojevalcev:

Turčinov ko listja in trave prihrulo na našo je vas,

10 Gl. tudi Turški plašč: narodna povestica iz Senožeškega okraja. Popotnik III, št. 12 (10. 12. 1882), str. 192 (arhiv ISN ZRC SAZU in Miklova Zala, Mir III, št. 10 /25. 5. 1884/, str. 78 /arhiv ISN ZRC SAZU/) (Mlakar 2019, 62).

11 Hladnik o odnosu do Turkov v tej povesti zapiše: "Da bi se svet potrdil v svoji nespremenljivosti in homogenosti, se v slovenskih turških povestih najpomembnejši Turki pogosto izkažejo za v Turke preoblečene Slovence.« $(2005,15)$

12 Tudi pesem Čaša nesmrtnosti tematizira islam, a se zdi, da je Aškerc tujo religijo uporabil le kot možnost upovedovanja lastnega filozofskega prepričanja o življenju in smrti, ne pa kot propagando ali kritiko islama. Vse navedene pesmi so bile objavljene v zbirki Balade in romance, 1890. 
morilo, da v breg iz nižave

joku se razlegal je glas.

Aškerc se je na svojih potovanjih osebno seznanil s svetom, ki Slovencem v 19. stoletju ni bil posebno znan in kamor tudi niso potovali. So se pa nekateri Slovenci vendarle seznanili z muslimanskim svetom, npr. Benedikt Kuripečič, ki je objavil Interarij - najstarejši popis potovanja skozi Bosno v turškem času - opis razmerja med Turki in podjarmljenimi prebivalci Balkana v 16. stoletju. Iz zgodovine je znano tudi to, da sta leta 1541 dva viteza, Jožef Lamberg in Nikolaj Jurišič, šla na avdienco k Sulejmanu Veličastnemu. (Vinkler 2011, 46-47) V 19. stoletju sta Miklošič leta 1851 in Nolija 1881 obiskala Carigrad (Žerjal Pavlin 2005, 410-426). Anton Aškerc je ta muslimanski svet pred potovanjem spoznaval ob knjižnih virih, saj je od leta 1879 po nemškem prevodu študiral Koran (Šmitek 1986, 69). Kulturno in religiozno neznani svetovi so ga povsem prevzeli; Turčijo, še posebno Carigrad, je opisal kot svet posebne lepote ter religiozne in kulturne raznolikosti. Aškerc je bil po mnenju Marije Boršnik "prvi slovenski pesnik v džamiji« (Aškerc 1946, 373). Podoba islama in muslimana je tako popolnoma drugačna $\mathrm{v}$ pesmih, ki jih je objavil po potovanju v Sarajevo in Carigrad, in sicer cikel Iz popotnega dnevnika (Lirske in epske pesmi 1896): v Sarajevu (Mohamedanki, V Husrev-begovi džamiji, Mujezin), v Carigradu (Na Galatskem mostu, Na urtu pred Hagijoj Sofijoj, Selamlik). Aškerc je v pesmi izrazil kritiko z družbenim položajem muslimanske ženske: „Čemu gosta ta koprena, / ki zakriva lica kras? / Kaj je mislil prerok modri, / zagrnivši tvoj obraz? // Hoče prerok mar zavidni, / naj le mož te gleda tvoj? / Ali je kot stvar nečisto / v koran te zapisal svoj? // Nikdar sanj ne sanjaš zlatih / o svobodi kristijan? - / Robstva jarma ne občutišs? / Harem ni ti - pretesan?« (Mohamedanki, Aškerc 1946, 185) Tudi v pesmi Haremski roži Aškerc $(1946,205)$ upesni položaj ženske kot tržnega blaga: »In hliniš mu čustva srca, / ki kupil kot lep kos blaga / na stambulskem nočnem te sejmu / za polno je mošnjo zlata?»

Aškerc se je prvič z islamom srečal že ob obisku sarajevske džamije leta 1886. Tam je spoznal, da se je slovanski svet povezal z islamom, ki ga je prakticiral Slovan v Bosni, prisiljeno ali prostovoljno: V Husrev-begovi džamiji, v Sarajevu, ko je prisostvoval molitvi, je islam dojemal kot enakovreden krščanstvu: »Po svoje jaz - vi pa po svoje / kot bratje častimo Boga; / molitev dobra i vaša, če dobrega vzdih je srca. [...] Ne moti vas 
"tujec« edini, / stoječi med vami neznan? / Ah, videti hotel sem samo, / kak Alaha moli Slovan.« $(1946,186)$ Tako lahko sklepamo, da je, sicer izhajajoč iz negativne percepcije islama, s svojo osebno izkušnjo srečevanja $z$ drugim in drugačnim vendarle premogel drugačen pogled na islam tako v popotniških opisih kot tudi v pesmih. Svetovni uspeh islama je Aškerc v pesmi Na mohamedanskem grobišču (Sarajevo) povezal z opisom muslimanskih nebes, ki mu je ob objavi pesmi v Ljubljanskem zvonu 1887 dodal pojasnilo, da je posnet po 37., 43. in 44. suri Korana, kar potrjuje, da je prebiral Koran - nekaj vrstic iz njega je kot moto zapisal tudi k pesmi Čaša nesmrtnosti. Predstavo nebes, ki so nedvomno zelo privlačna, Aškerc pripisuje zvijačnosti preroka Mohameda: ${ }^{13}$ "Lep raj si ustvaril, o prêrok! / Ž njim pol si osvójil zemljé, / osrečil si ž njim milijone ... / Poznal si - človeško srce.» (Aškerc 1946, 189) Carigrad mu je bil pri srcu tudi zaradi večkulturnosti in večnacionalnosti ter raznolikosti religij, ki so takrat sobivale v dialogu. ${ }^{14}$ To je tematiziral v pesmi Na Galgatskem mostu: »Bog živi te, Turek, Čerkes, Arabljan, / pozdravljam te, brate balkanski! / Kaj novega, Grk, Perzijan, je pri vas? / Ti tudi tu, sinko ciganski? // [...] Različnih jezikov, noš, bój smo in ver, / pa vendarle vsi smo si bratje! / In vendar edini smo vsi si vsaj v tem, / da diven zares Carigrad je!« $(1946,202)$ V pesmi Na urtu pred Hagijoj Sofijoj, ki jo je podrobno opisal tudi v potopisu Izlet $v$ Carigrad 1893, pa se povrne v preteklost, ko je bilo to svetišče še krščansko in so se za njegov novi religiozni status odvijali hudi boji: »Ura, ura ...! In grom topov! / Krvav se boj pred manoj bije ... / Poslednji se razvije boj / okoli Hagije Sofije."// Kdo zmaga? ... Kdo bo posihdob / v svetišču tem Bogú se klanjal? / In zvon bo ali mujezin / molitve čas poslej oznanjal?« (1946, 204)

Podoba muslimana ali Turka iz folklore in literature 19. stoletja prikazuje ontološko, religiozno in kulturno drugačnega tujega, kar povzroča odpor. Toda ko pesnik Aškerc konec 19. stoletja obišče muslimansko okolje, gre za časovni in personalni odmik od obdobja turških vpadov, in takrat se stereotipizacija prekine. Drugačna izkušnja stika z islamom ga celo navduši

13 Tematizacija percepcije takih nebes je znana tudi iz romana Alamut Vladimirja Bartola (1938), ki je tematiziral muslimanski svet $\mathrm{v}$ fanatizmu in izkrivljenem tolmačenju Korana.

14 V Carigradu je veljal sistem »milet«: »Milet je združeval pripadnika različnih ver v relativno avtonomne, varne, notranje hierarhično urejene enote; podrejene carigrajskemu sultanu. /...]/ Njegovo bistvo je bilo v tem, da so bili pripadniki različnih religij čim bolj ločeni, da bi se tako ognili konfliktu ali celo konfliktom."(Velikonja 1998, 76) 
in v njem odkriva podobnosti s krščanstvom, hkrati pa eksotiko, ki ga še posebej privlači. A še vedno se v pesmih skrivajo kritični toni.

Negativna podoba pripadnika islama $\mathrm{v}$ folklori in literaturi prevladuje, saj je kolektivni spomin na turško divjanje in povezanost islama in muslimana z nasiljem izjemno trdovraten.

\section{Pred prvo svetovno vojno in med njo}

Od leta 1878, ko je AO z vojno pridobila bosansko ozemlje, pa do prve svetovne vojne sta se Katoliška cerkev in obenem islamski aktivizem okrepila, saj AO ni posegala v religijsko strukturo tedanje Bosne. Poskusila je le ekonomsko in izobraževalno razviti ozemlje. (Velikonja 1998) Prva svetovna vojna je bila tematizirana $\mathrm{v}$ številnih pesemskih in proznih delih avtorjev, kot so France Bevk, Janez Jalen, Silvin Sardenko, Stanko Majcen, Ferdo Kozak, odnos med muslimani in nemuslimani pa v literarne tematizacije ni našel poti. Sobivanje različnih religij med prvo svetovno vojno je bilo nakazano le v ljudski pesmi in delno pri Cankarju. ${ }^{15}$

Cankar je po težkem obdobju bivanja na Dunaju leta 1909 obiskal Sarajevo, kjer je njegov brat opravljal službo katoliškega duhovnika, in hipotetično lahko rečemo, da se je seznanil tudi z islamom, čeprav naj bi po nekaterih raziskavah tam znova našel katoliško vero.

V času prve svetovne vojne so se na soški fronti borili prebivalci AO, ki so bili tako bosanske/bošnjaške provenience kot slovenske. Kot poroča pisatelj Vinko Bitenc v romanu Sončne pege (1934), ${ }^{16}$ so bili avstrijski in madžarski častniki zelo sovražni do Slovanov, in morda so se prav zato Slovenci in Bosanci/Bošnjaki lažje povezali. Na bojnih poljanah ni bila pomembna veroizpoved, temveč povezanost ljudi v boju proti sovražniku pa tudi v eksistencialni stiski, saj smrt ne vpraša po narodnosti ali verski pripadnosti.

15 Ta razprava ne omogoča poglobljene raziskave slovenske literature, ki morda tematizira srečanje med muslimanom in kristjanom med prvo svetovno vojno.

16 Madžarski poročnik je takole izrazil sovražnost do Slovanov: »Molčite vi, vi - sie slawischer Hund!« (Bitenc 2015, 36) 
Cankar v delu Slovenci in Jugoslovani leta 1913 sicer ugotavlja, da so med Slovenci in drugimi južnoslovanskimi narodi velike kulturne razlike - da so "po krvi bratje, po jeziku bratranci, po kulturi, ki je sad večstoletne vzgoje, pa smo si veliko bolj tuji« (1976, 322), a vojna preseže vse, poveže ljudi različnih kultur in veroizpovedi med seboj, le da se borijo na isti strani. Doživljanje prve svetovne vojne je odsevalo tudi v Podobah iz sanj (1917). Cankar je sicer tematiziral predvsem dogajanje v barakah v Judenburgu, kjer je bil 17. slovenski pešpolk, poznal pa je tudi dogajanje na soški fronti, kjer so se Slovenci in Bosanci/Bošnjaki skupaj borili proti Italijanom; takrat religiozna različnost seveda ni bila več pomembna. Bosanski katoliki in muslimani so oblekli avstro-ogrsko uniformo, medtem ko je večina pravoslavnih prestopila Drino in se priključila srbski ali črnogorski vojski. ${ }^{17}$ Pomemben kontekstualni podatek je, da so Cankarja vpoklicali v vojsko leta 1915 in je bil nekaj časa v Judenburgu, kjer so služili slovenski fantje v 17. pehotnem polku, a so ga zaradi slabega zdravja kmalu odpustili. Slovenski fantje so v Judenburgu peli slovenske ljudske pesmi, med njimi tudi $O j$, ta vojaški/soldaški boben, Fantje se zbirajo idr., bosanski vojaki pa O bosanski hrabri sine. ${ }^{18}$ Zato je docela verjetno, da je Cankar pesem Oj, ta soldaški boben slišal, ko je bil tam, in nato vnesel njen prvi verz v črtico Ranjenci. V njej Cankar izpostavlja zgolj človeški vidik, ki poudarja presežno razsežnost, človečnost, smrt in boj za ohranitev življenja kot tisto, kar kljub narodnostnim in verskim razlikam ljudi poveže v času, ko so v smrtni nevarnosti. Vsi so lahko ubiti, ranjeni, vsak se priporoča svoji transcendenci, ki nikogar ne ogroža. (1976, 270-274) Enako povezanost v bolesti tematizira tudi v črtici Pobratimi. (1976, 318-321) Hipotetično bi lahko rekli, da je prva svetovna vojna prav zaradi eksistencialne ogroženosti vseh udeležencev prinesla odsotnost bojazni pred drugim, ki je bil muslimanske vere.

17 »Avstro-Ogrska je maksimalno izkoristila vojaški potencial BiH. Pred koncem leta 1917 je bilo v bošnjaških enotah že 298.773 vojakov. Med vojno je bilo v BiH mobiliziranih 17,2 odstotka vseh moških do 16. do 70. leta. Bošnjaki so bili kruti in pogumni v boju, vendar izjemno solidarni med seboj. Mnogi jih opisujejo kot vojake, ki so šli v vojno mirni in s prepričanjem, da se bo zgodila usoda. Temu so rekli kismet."(Pašić 2014)

18 Schüler 2000, Soldatenlieder der k.uk. Armee - zgoščenka, izdana na Dunaju. (CD 2/11, Ph 2561, 71-72, posneto med slovenskimi vojaki 1916 v Judenburgu in 29. januarja 1916 med bošnjaškimi vojaki v Budimpešti, posnel Leo Hajek.) Tudi Bitenc v knjigi Sončne pege v kratki zgodbi Na predstraž $i$ poroča o petju med vojaki: „Peli so staroslavno pesem o Radeckyju, o Laudonu, potem o Bosni in Hercegovini in druge.« $(2015,176)$ 
Prva svetovna vojna je torej obdobje, ko se verske razlike umaknejo in se ljudje povežejo v strahu in upu za življenje.

\section{Obdobje po letu 1991}

V obdobju po letu 1991 je v literaturi upodobljen odnos do islamskih pripadnikov, s katerimi so Slovenci dotlej sobivali v skupni državi in jih dojemali kot pripadnike bratske republike, hkrati pa tudi kot gradbene delavce, s katerimi so delali tudi v arabsko-afriških deželah, kjer je imela nekdanja Jugoslavija svoj "gradbeni patronat«. V nekaterih romanih so tako prikazani tudi pripadniki islama iz teh dežel, pri čemer prevladujejo etnični stereotipi o Arabcih, npr. v romanu Karfanaum ali as killed Maje Novak. Avtorica slovenskega gradbenega delavca tematizira prek petja pesmi Fantje se zbirajo 'z kranjske dežele $(1998,30)$, nato pa se srečata predstavnik slovenskega naroda in pripadnik islama iz arabsko-afriških dežel: »Začel se je ramadan. Muslimani od sončnega vzhoda do sončnega zahoda niso smeli jesti ne kaditi ne piti vode. Žeja jih je strla. [...] Abu Rub se je postil do poldneva prvega dne. Potem je moško poslal k vragu duhovščino v Meki ter Alaha in zdirjal k Juditi po cigareto." (Novak 1998, 72-73) V romanu Marjana Tomšiča Grenko morje: roman o aleksandrinkah (2002), ki izhaja iz mita o lepi Vidi, tematizirani v imagološki podobi Slovenk kot aleksandrink, ki služijo kot dojilje ali služkinje, varuške ipd. v Egiptu, Tomšič stereotipno upodablja slovensko žensko kot žrtev, ki je podrejena cerkvenim pravilom, a tudi moške like, ki so večinoma nasilni: »Največkrat so nasilneži muslimani ali predstavniki vzhodnoevropskih narodov.«(Mihurko Poniž 2011, 50) Zbližanje z drugim, ki je muslimanske vere in temne polti, je skoraj nemogoče. Gre za družbeni konstrukt drugačnosti, ki ga ženska prinese od doma; resda ji prav katoliški duhovnik prigovarja, da ljubezen lahko premaga družbeno pogojene razlike, vendar gre pri tem morda le za vprašanje verske in moške nadvlade: »O ti moj ljubi Bog! Le kaj naj ti še rečem? Le kaj? Če se res ljubita, če sta res trdno odločena ..." - »Ampak vera, pater, vera! Jaz sem kristjanka, on je musliman. Moja koža je bela, njegova črna kot noč." (Tomšič 2002, 102) To so bile res zgolj reprezentacije, in ne dejstva. Tomšič je upodobil žensko aleksandrinko kot tipizirano nebogljeno žensko ali pa kot avanturistko. Resničnost je bila drugačna. Odnos med muslimanom in slovensko žensko je bil večplasten. Ne samo negativen, tudi pozitiven. 
Naslednji romani - Tito, amor mijo (2005) Marka Sosiča, Čefurji raus (2008) Gorana Vojnovića, Balkan Sobranie Jožeta Snoja (2012) - nakazujejo prizanesljivejše dojemanje islamskega drugega. V glavnem gre za posameznika - in za njegov položaj v večkulturni družbi - ki pa je obravnavan skoraj naklonjeno. Jože Snoj v romanu Balkan Sobranie tematizira srečevanje različnih narodov socialistične Jugoslavije ob služenju vojaškega roka, kjer so se kulturne in verske razlike sicer opazile, a niso vplivale na odnose med pripadniki različnih veroizpovedi ali kultur. Bolj kritično so izpostavljeni napol izobraženi oficirji, ki so se znašali nad vsemi. V romanu Gorana Vojnovića Čefurji raus sta Srb (Marko) in musliman (Adnan), oba iz Bosne, a oba pripadnika tretje generacije priseljencev iz Bosne v Slovenijo, prijatelja, ki se počutita enako izključena iz obeh nacionalnih in kulturnih identitet, ki jima pripadata (2008, 94-95). V romanu M. Sosiča Tito, amor mijo (2005) deček, ki živi v Trstu, kjer je odnos večinskega naroda do Slovencev negativen - so »schiavi«, muslimanko Lejlo spoštljivo opazuje in ugotavlja, da so pripadniki tuje vere velikokrat bolj pošteni kot ljudje v njegovem okolju, pa naj bodo to Slovenci ali Italijani. Njegov opis je nevtralen, celo pozitiven, nič mu ni tuje, le zanimivo: »Lejla na dvorišču kleči in se sklanja proti soncu, potem se s čelom dotakne zemlje in ostane nekaj časa tako, upognjena na zemljo. Tata pravi, da Lejla moli proti soncu zunaj na dvorišču, ker je muslimanka, in muslimani, pravi tata, imajo svojega boga, ki se imenuje Alah [...] Zdi se mi, kakor da posluša zemljo in vodo spodaj v luknjah in jamah, ki jih je vse polno na Krasu.«(153)

Odnos do muslimanskega drugega je torej prizanesljivejši, morda so negativne le tiste podobe, ki izhajajo iz arabskega sveta, sveta, ki je bil preveč oddaljen od nas in ga nismo poznali. Podobe jugoslovanskih muslimanov pa so povezane s kulturnim modelom izgubljenega »bratstva in enotnosti« iz nekdanje skupne države, morda tudi z jugonostalgijo. V Sosičevem romanu pa je povezanost s Slovani druge vere povezanost z nekom, ki ni sovražen, kot so sovražni pripadniki fašističnih struktur Trsta, kjer je živela in še živi slovenska manjšina.

\section{Sklep}

Ne doktrina ne zgodovinska resnica ne moreta omogočiti dialoga, še toliko manj pa to velja za fiktivno tematizacijo resničnosti, zato je bila analiza 
folklornih in literarnih besedil tekstualna in kontekstualna, ni pa posegala $\mathrm{v}$ zapletene teološke temelje Korana in presojala besedil na podlagi islamskih teoloških resnic. Razprava je poskusila zajeti različnost odnosov do muslimanskega drugega, tako kot je bilo mogoče razbrati iz reprezentacij, ki niso le odsev resničnosti, temveč tudi vpetosti ustvarjalcev v družbenopolitične sisteme, ki oblikujejo njihov pogled na svet. Ali lahko folklorizacije in literarizacije s svojimi bodisi slabšalnimi bodisi pozitivnimi podobami in razmerji med različnimi religijami in kulturami vplivajo na splošno sprejeto družbeno podobo muslimana, ki ima nato za posledico tak ali drugačen odnos do njega? In še, ali sta ta predstava in z njo povezan odnos nato odločilno vplivala na razmerja do muslimanskega drugega? Odgovor bi lahko bil naslednji: Zdi se, da je folklorna podoba drugega, ki je izhajala iz odsevov resničnosti in kolektivnega kulturnega spomina na kontinuirano nasilje islama v obdobjih turških vpadov, zarisala podlago za islamofobijo, ta pa je lahko temelj nezaupanja do nosilcev islama, zlasti če besedila ostanejo nereflektirana in negativna podoba skoraj »konzervirana«. Folklorna besedila so imela tudi vlogo sporočanja takih ali drugačnih dogodkov, bila so celo svarilna. Zato razlogi za negativno ali pozitivno podobo izhajajo iz resničnosti, iz zgodovinskih in družbenih dejstev, in pri folklori lahko z gotovostjo rečemo, da gre za ustvarjalno podobo resničnosti, medtem ko gre pri literaturi, ki je avtorska in ne prinaša literarne resnice, temveč fiktivno podobo, za interpretacijo resničnosti. Tam pa je mogoča tudi pozitivna podoba muslimana. Zato lahko ubesedena podoba kot občutena stvarnost pokaže tudi drugačen obraz drugega in tako ustvari preskok iz negativne percepcije $\mathrm{v}$ tolerantnejšo, a to se zgodi šele $\mathrm{v}$ prepoznavanju drugega, ki se ne zdi tako drugačen, tako da lahko tudi v kulturni in verski različnosti prepoznamo bližino. To se je v slovenski literarni zgodovini zgodilo razmeroma pozno, z Aškercem, ko se je sam srečal z islamom, v sodobni slovenski literaturi pa se prepletajo tako pozitivne kot negativne reprezentacije drugega, vendar so popolnoma avtorske. Slovstvena podoba islama tako ni recept za dialog z drugim in drugačnim, je le možnost, da prek teh tematizacij ugotavljamo enoplastnost ali večplastnost teh podob. Ne moremo pa v analizo teh podob niti v njihov kontekstualni okvir aplicirati sodobnih medreligijskih trendov. Sodobna spoznanja, da dialog lahko poteka le na osebni ravni (Urvoy 2015, Osredkar 2018), da je mogoč le pri sprejemanju kulturne in religiozne različnosti, ki pa izhaja iz preseganja doktrinalnih in dogmatskih zapovedi tako islama kot krščanstva, vidimo tudi v nekaterih analiziranih 
besedilih. Zato je pomembno poudariti izstop iz posploševanja, ki ga goji ideologija, in vstop v individualizacijo, ki je mogoč v folklori in literaturi. Zgodbe so nedvomno močnejše od ideologij.

\section{Kratici}

A0 Avstro-Ogrska

BiH Bosna in Hercegovina

\section{Reference}

Aškerc, Anton. Zbrano delo. 1946. Balade in romance. Lirske in epske poezije. Ljubljana: DZS, 1. knjiga.

Baskar, Bojan. 2012. »Prvi slovenski pesnik $\mathrm{v}$ džamiji : orientalizem $\mathrm{v}$ potopisih pesnika z imperialnega obrobja. V: Božidar Jezernik, ur. Imaginarni Turek, 127-144. Ljubljana: Zavod Republike Slovenije za šolstvo.

Bitenc, Vinko. 2015. Sončne pege. Smlednik: samozal.

Breyer, Mirko. 1843. Odraz pobjede kod Siska (1593) u domačoj i stranoj književnosti. Časopis za hrvatsku povjest: 244-259.

Cankar, Ivan. 1976. Izbrano delo I. Slovenci in Jugoslovani. Ljubljana: Mladinska knjiga, 314-326.

- - -. 1976. Izbrano delo VII. Podobe iz sanj. Ljubljana: Mladinska knjiga.

Chambers, Claire. 2015. Britain Through Muslim Eyes: Literary Represenatations. 1780-1888. New York: Palgrave Macmillian.

Cheesman Tom. 2007. Novels of TurkishGerman Settlement: Cosmopolite Fictions. Rochester, NY: Camden House.

- - -. 2012. 'Nathan without the Rings: The Postmodern Religion in Nathan Messias'. V: Tom Cheesman in Karin E. Yeşilada, ur. Feridun Zaimoglu, 117-44. Oxford: Peter Lang.

Dapit, Roberto. 2017. Rezijanska Linčica Turkinčica kot splošno slovenski motiv drugosti. Studia mythologica Slavica 20: 179-203. Https://doi.org/10.3986/ sms.v20i0.6665

Goethe, Johann Wolfgang von. 1819. Westöstlicher Divan. Stuttgart: Cottaischen Buchhandlung.

Golež Kaučič, Marjetka et al. 2007a. Slovenske ljudske pesmi V. Ljubljana: Slovenska matica in Založba ZRC SAZU.

Golež Kaučič, Marjetka. 2007b. Slovene folk song at the crossroads of influences, contacts, and oppositions of East, West, North, and South. Slovene studies. 29: 3-17. Https://doi.org/10.7152/ssj.v29i1. 14029 .

- - -. 2013. »Fantje se zbirajo -«: vojna in vojaki v slovenski ljudski pesmi (Zbirka Folkloristični zvezki, 1). Ljubljana: Založba ZRC, ZRC SAZU.

Gingrich, A. 1998. Frontier Myths of Orientalism: The Muslim World in Publica and Popular Cultures of Central Europe. V: Bojan Baskar, Borut Brumen, ur. MESS: Mediteranean Ethnological Summer School, 99-128. Ljubljana: Inštitut za multikulturne raziskave.

Gruden, Josip. 1912. Zgodovina slovenskega naroda II. Celovec.

Hladnik, Miran. 1994. Turki v slovenski zgodovinski povesti. Slavia Meridionalis 11: 253-263. 
- - -. 2005. Z njihovimi ženskami se poročajte ali soočanje kultur v slovenskem zgodovinskem romanu. V: Marko Stabej, ur. Večkulturnost v slovenskem jeziku, literaturi in kulturi, 27. 6.-15. 7. 2005 (41. seminar slovenskega jezika, literature in kulture), 11-19. Ljubljana: FF. Dostopno na: https://centerslo.si/ wp-content/uploads/2015/ 10/41zbornik-za-splet.pdf.

Jaklitsch Jakše, Katarina. 2012. Podoba Turkov v slovenski dramatiki. V: Mateja Pezdirc Bartol, ur. Obdobja 31. Slovensk a dramatika, 103-110. Ljubljana: Center za slovenščino kot drugi ali tuji jezik, FF UL.

Jezernik, Božidar. 2011. Divja Evropa. Ljubljana: Slovenska matica.

- - -. Imaginarni Turek. 2012. Ljubljana: Zavod Republike Slovenije za šolstvo.

Kotnik, France (zbral in uredil). 1957. Storije. Koroške narodne pripovedke in pravlijce. Celovec: Družba sv. Mohorja.

Kumer, Zmaga, et al. 1970. Slovenske ljudske pesmi I. Ljubljana: Slovenska matica.

Kumer, Zmaga. 1996. Vloga, zgradba, slog slovenske ljudske pesmi. Ljubljana, Založba ZRC.

May, Yomb. 2009. 'Goethe, Islam, and the Orient: The Impetus for and Mode of Intercultural Encounter in the Westöstlicher Divan', V: James Hodkinson in Jeffrey Morrison, ur. Encounters with Islam in German Literature and Culture, 89-107. Rochester, NY: Camden House.

Mastnak, Tomaž. 2001. Naša Evropa. V: Tomaž Mastnak in drugi, ur. Obrazi naše Evrope, 9-22. Ljubljana: Mirovni inštitut, Inštitut za sodobne družbene in politične študije.

Mihurko Poniž, Katja. 2011. Reprezentacije aleksandrink v prozi Marjana Tomšiča. Dve domovini 34: 47-62.

Mlakar, Anja. 2019. Skrivnostni tujec in demonski sovražnik. Drugi in Drugost v slovenski slovstveni folklori. (Zbirka Studia mythologica Slavica. Supplementa; suppl. 14). Ljubljana: Založba ZRC, ZRC SAZU.
Monta, Anthony. 2011. Introduction: The Place of Islam in Contemporary European literature. Balkan Literature 43: $120-122$.

Novak, Maja. 1998. Karfanaum ali as killed. Ljubljana: Cankarjeva založba.

Osredkar, Mari Jože. 2018. V začetku je bil dialog. Bogoslouni vestnik 78: 17-31.

Pageaux, Daniel-Heri. 2008. Imagološke razprave. Ljubljana: ISH.

Pašić, Ahmed. 2014. Bosanski fesi v prvi svetovni vojni. Gorenjski glas, 29. 7. 2014.

Potisk, Martina. 2013. Medkulturnost v literaturi: položaj islama v sodobnem slovenskem romanu po letu 1991. Slavica Tergestina 15: 156-180.

Rushdie, Salman. 1991. Imaginary Homelands: Essays and Criticism, 1981-1991. London: Granta.

Said, Edward. 1996. Orientalizem: zahodnjaški pogledi na Orient. Ljubljana: ISH.

Schüler, Dietrich, ur. 2000. Tondokumente aus Phonogramarchiv der Österreichen Akademiee der Wissenschaften. Gesamteausgabe der Historischen Bestände 1899-1950 - Serie 4: Soldatenlieder der k. u. k. Armee. OEAWPHA CD 2/ 11, Ph 2561. Wien: Verlag der Österreichische Akademie der Wissenschaften.

Simoniti, Vasko. Bitka pri Sisku. Enciklopedija Slovenije 1. Ljubljana: Mladinska knjiga: 277-278.

Sosič, Marko. 2005. Tito, amor mijo. Maribor: Litera.

Šmitek, Zmago. 1986. Trubar in Turki. V: 16. stoletje v slovenskem jeziku, književnosti in kulturi (mednarodni simpozij v Ljubljani od 27. do 29. junija 1984), 159-169. Ljubljana: FF.

Šterbenc, Primož. 2005. Šitit, doktrina in zgodovina odnosa s Suniti. Ljubljana: Fakulteta za družbene vede.

- - -. 2017 Kako je islamska civilizacija prispevala k razvoju zahoda. Dostopno na: https://www.youtube.com/ watch? $v=1$ zesrzbfzqs.

Štrekelj, Karel. 1895-1898. Slovenske narodne pesmi, 1895-1898. Ljubljana: Cankarjeva založba. 
Todorova, Maria. 2001. Imaginarij Balkana. Imaginarij Balkana. Ljubljana: Vita Activa.

Tomšič, Marjan. 2002. Grenko morje: roman o aleksandrinkah. Ljubljana: Kmečki glas.

Turk, Meta. 2010. Turški vpadi na Cerkniško in z njimi povezane pripovedke in pripovedi. Diplomsko delo.

Urvoy, Marie Thérèse. 2016. Aperçu sur le comunatés chétiennes ou Moyen-Orient. Bogoslovni vestnik 76: 101-128.

Velikonja, Mitja. 1996. Masade duha, razpotja sodobnih mitologij. Ljubljana: Znanstveno in publicistično središče.
Vinkler, Jonatan. 2011. Uporniki, "hudi farji i in Hudičevi soldatje. Podobe iz evropskih in "slovenskih"imaginarijev 16. stoletja. Pedagoški inštitut. Digitalna knjižnica. Disertationes 17. Https://doi. org/10.32320/978-961-270-094-2.

Voje, Ignacij. 1996. Slovenci pod pritiskom turškega nasilja. Ljubljana: ZIFF.

Vojnović, Goran. 2008. Čefurji raus. Ljubljana: Študentska založba.

Zalta, Anja. Muslims in Slovenia. Islamic Studies 44: 93-112.

Žerjal Pavlin, Vita. 2005. Stritarjevi in Aškerčevi popotni cikli. Slavistična revija 53: 399-426. 